\title{
Protective Effects of a Monoclonal Antibody to a Mannose-Binding Protein of Acanthamoeba culbertsoni
}

\author{
A-Young Park ${ }^{*}$, A-Young Kang* and Suk-Yul Jung ${ }^{\dagger, * *}$ \\ Department of Biomedical Laboratory Science, Molecular Diagnosis Research Institute, \\ Namseoul University, Chungnam 31020, Korea
}

\begin{abstract}
Acanthamoeba culbertsoni is the causative agent of granulomatous amoebic encephalitis (GAE), a condition that predominantly occurs in immunocompromised individuals and which is typically fatal. A mannose-binding protein (MBP) among lectins was shown to have strong A. castellanii pathogenic potential when correlated with major virulence proteins. In this study, protective effects were analyzed using the monoclonal antibody to A. culbertsoni MBP by quantification and were also compared with other free-living amoebae. For the amoebial cytotoxicity to the target cell, amoeba trophozoites were incubated with Chinese hamster ovary (CHO) cells. For the protective effects of antibodies, amoebae were preincubated with them for $4 \mathrm{~h}$ and then added to the target cells. After $24 \mathrm{~h}$, the supernatants were collected and examined for host cell cytotoxicity by measuring lactate dehydrogenase (LDH) release. The cytotoxicity of A. culbertsoni to the $\mathrm{CHO}$ cells showed about $87.4 \%$. When the monoclonal antibody was pre-incubated with A. culbertsoni, the amoebial cytotoxicity was remarkably decreased as shown at LDH release (1.858 absorbance), which was represented with about 49.9\%. Taken together, it suggested that the monoclonal antibody against MBP be important to inhibit the cytotoxicity of A. culbertsoni trophozoites to the target cell. The antibody will be applied into an in vivo functional analysis, which would help to develop therapeutics.
\end{abstract}

Key Words: Acanthamoeba culbertsoni, Mannose-binding protein, Monoclonal antibody, Cytotoxicity

Acanthamoeba culbertsoni is the causative agent of granulomatous amoebic encephalitis (GAE), a condition that predominantly occurs in immunocompromised individuals and which is typically fatal (Schuster and Visvesvara, 2004; Walochnik et al., 2008).

Acanthamoeba has been of interests due to (i) produce serious human infections associated with a rise in the number of immunocompromised patients and contact lense wearers,

(ii) its potential role in ecosystems and (iii) its ability to act as a host/reservoir for microbial pathogens (Khan, 2006).
Lectins are well known to be important to induce cytotoxicity in target cells by $A$. castellanii causing amoebic keratits (AK). Among them, a mannose-binding protein (MBP) was shown to have strong $A$. castellanii pathogenic potential when correlated with major virulence proteins (Garate et al., 2006; Panjwani, 2010; Kim et al., 2012). The MBP was cloned and revealed to possess about $130 \mathrm{kDa}$-molecular weight (MW). However, in A. culbertsoni, it is not well reported about the MW and functional roles yet. Recently, we reported the production of the monoclonal antibody to $A$.

Received: November 1, 2018 / Accepted: December 6, 2018

*Researcher, ${ }^{* *}$ Professor.

† Corresponding author: Suk-Yul Jung. Department of Biomedical Laboratory Science, Molecular Diagnosis Research Institute, Namseoul University, 91, Daehak-ro, Seonghwan-eup, Seobuk-gu, Cheonan-city, Chungnam 31020, Korea.

Tel: +82-41-580-2723, Fax: +82-41-580-2932, e-mail: syjung@nsu.ac.kr

(C) The Korean Society for Biomedical Laboratory Sciences. All rights reserved.

(c) This is an Open Access article distributed under the terms of the Creative Commons Attribution Non-Commercial License (http://creativecommons.org/licenses/by-nc/3.0/) which permits unrestricted non-commercial use, distribution, and reproduction in any medium, provided the original work is properly cited. 
Table 1. Protective effects of DG11 to the cytotoxicity of $\boldsymbol{A}$. culbertsoni to CHO cells. $A$. culbertsoni was pre-incubated with DG11 of a monoclonal antibody for $4 \mathrm{~h}$ and then LDH release was measured. Lysed CHO; CHO cells treated with a lysis buffer for 30 min. Lysed $A$. culbertsoni; A. culbertsoni treated with a lysis buffer of Triton X-100 for 30 min at $37^{\circ} \mathrm{C}$., SD; standard deviation. Data were absorbances measured under $490 \mathrm{~nm}$. The experiments were performed in triplicate three times

\begin{tabular}{|c|c|c|c|c|c|c|c|}
\hline Exp. & Medium & $\mathrm{CHO}$ & $\begin{array}{l}\text { Lysed } \\
\text { CHO }\end{array}$ & $\begin{array}{c}\text { Lysed } \\
\text { A. culbertsoni }\end{array}$ & $\begin{array}{c}\mathrm{CHO}+ \\
\text { A. culbertsoni }\end{array}$ & $\begin{array}{c}\mathrm{CHO}+ \\
\text { A. culbertsoni }+ \\
\text { polyclonal serum }\end{array}$ & $\begin{array}{c}\mathrm{CHO}+ \\
\text { A. culbertsoni }+ \\
\text { DG11 }\end{array}$ \\
\hline $1^{\text {st }}$ & 0.738 & 1.541 & 2.911 & 0.820 & 3.200 & 1.770 & 1.867 \\
\hline $2^{\text {nd }}$ & 0.742 & 1.563 & 2.955 & 0.827 & 3.255 & 1.899 & 1.809 \\
\hline $3^{\text {rd }}$ & 0.759 & 1.712 & 2.886 & 0.770 & 3.304 & 1.919 & 1.898 \\
\hline Mean & 0.746 & 1.605 & 2.917 & 0.806 & 3.253 & 1.863 & 1.858 \\
\hline SD & 0.011 & 0.093 & 0.035 & 0.031 & 0.052 & 0.081 & 0.045 \\
\hline
\end{tabular}

culbertsoni MBP in 2018 (Kang et al., 2018). Antibodies against Naegleria fowleri antigens, another pathogenic freeliving amoeba have proven useful to diagnose infections in experimental animals (Ryu and Im, 1992; Lee, 2007). In this study, protective effects were analyzed using the monoclonal antibody to $A$. culbertsoni MBP by quantification and were also compared with other free-living amoebae.

A. culbertsoni trophozoites (ATCC NO. 30171; Kim et al., 1988; Kong et al.,1993) were grown without shaking in $12 \mathrm{~mL}$ of PYG medium (proteose peptone $0.75 \%(\mathrm{w} / \mathrm{v})$ (Kisan Bio, Seoul, Korea), yeast extract $0.75 \%$ (w/v) (Kisan Bio, Seoul, Korea) and glucose $1.5 \%$ (w/v) (Sigma-Aldrich Co., St. Louis, MO, USA)) in a $75 \mathrm{~T}$ culture flask at $25^{\circ} \mathrm{C}$. A. castellanii (ATCC NO. 50492), In addition, briefly, pathogenic N. fowleri (Carter Nf69 strain, ATCC 30215) was axenically cultured at $37^{\circ} \mathrm{C}$ in Nelson's medium (Seong et al., 2017). CHO cells were cultured with Earle's minimum essential medium (EMEM) containing 10\% fetal bovine serum at $37^{\circ} \mathrm{C}$ in a $5 \% \mathrm{CO}_{2}$ incubator (Kang et al., 2005).

To determine the protective effects of the monoclonal antibody which was produced and cloned, that is, DG11, cytotoxicity assay was performed as previously described (Sissons et al., 2005). The DG11 monoclonal antibody was classified with IgM isotype (Kang et al., 2018). In brief, for the amoebial cytotoxicity to the target cell, amoeba trophozoites $\left(2 \times 10^{5}\right.$ amoebae $/ 0.5 \mathrm{~mL} /$ well $)$ were incubated with $\mathrm{CHO}$ cells in EMEM. The plates were observed periodically for monolayer disruptions under a phase-contrast microscope for up to $24 \mathrm{~h}$. For the protective effects of antibodies, amoebae were pre-incubated with them for $4 \mathrm{~h}$ and then added to the target cells. After $24 \mathrm{~h}$, the supernatants were collected and examined for host cell cytotoxicity by measuring lactate dehydrogenase $(\mathrm{LDH})$ release (cytotoxicity detection kit; Roche Applied Science, Lewes, East Sussex, UK). In brief, the supernatants of the co-cultures were assessed for the presence of lactate dehydrogenase (LDH), the release of which is considered an estimate of cell death. The percentage LDH release which was measured by absorbance under $490 \mathrm{~nm}$ was calculated as follows: experimental $\mathrm{LDH} \times 100 \% /$ maximum $\mathrm{LDH}=\%$ cytotoxicity.

In results, with regarding the cytotoxicity of $A$. culbertsoni, $\mathrm{CHO}$ cells were shown morphologically severe destruction as observed at $24 \mathrm{~h}$ incubation (data not shown). The destruction of the $\mathrm{CHO}$ cells was described with LDH release shown at Table 1 . The $\mathrm{CHO}$ cells by co-incubation of $A$. culbertsoni trophozoites were proven mostly death (2.917 absorbance) as similar with whole death of LDH complete lysis (3.253 absorbance). The LDH release was calculated into \% cytotoxicity (Fig. 1 ). That is, the cytotoxicity of $A$. culbertsoni to the $\mathrm{CHO}$ cells showed about $87.4 \%$. When the monoclonal antibody of DG11 was pre-incubated with A. culbertsoni, the amoebial cytotoxicity was remarkably decreased as shown at LDH release (1.858 absorbance) in Table 1, which was represented with about $49.9 \%$ at Fig. 1. On the other hand, polyclonal serum obtained from BALB/c mice 4 weeks post-injection with MBP antigen also showed protective effects (about 50\%) as similar with the monoclonal antibody of DG11 at Fig. 1. Based on the \% cytotoxicity at 
Fig. 1, the protective effects of the monoclonal antibody of DG11 were shown about $37.5 \%$. Taken together, it suggested that the monoclonal antibody of DG11 be important to inhibit the cytotoxicity of $A$. culbertsoni trophozoites to the target cell.

The monoclonal antibody of DG11 is reported A. culbertsoni MBP-specific. To understand the cross-reactivity by the cytotoxicity assay, LDH assay was performed using other pathogenic free-living amoebae, e.g., A. castellanii, $N$. fowleri. The LDH release could be useful to analyze the cytotoxicity and protectivity with numerical value for the quantification. As shown at Table 1 and Fig. 1, the cytotoxicity of A. culbertsoni and protective effects of the monoclonal antibody of DG11 were similar in Table 2 and Fig. 2.

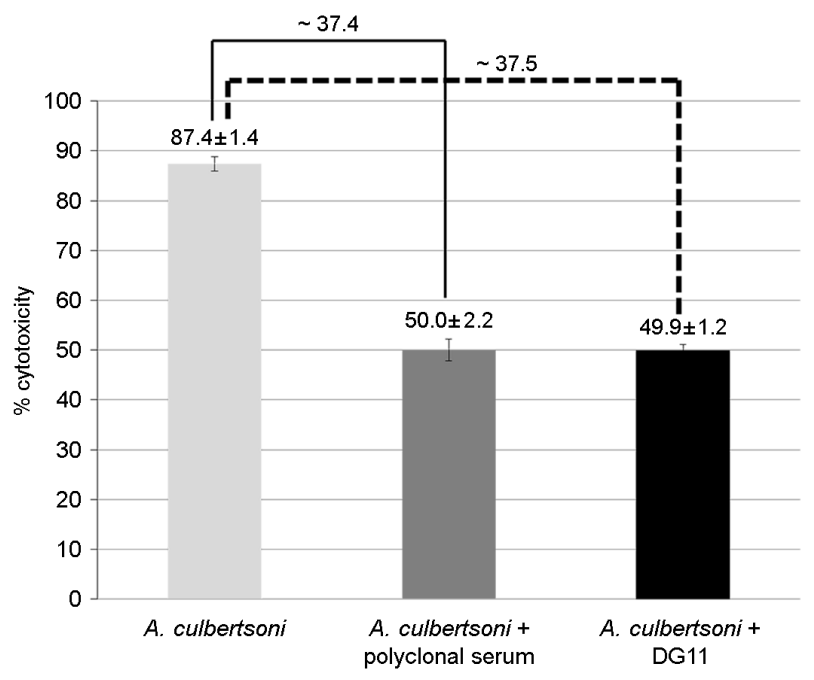

Fig. 1. Cytotoxicity of $A$. culbertsoni and protective effects of DG11 to the amoeba. Based on the LDH assay shown at Table 1, the cytotoxicity was calculated with percent value.
With A. culbertsoni, A. castellanii and N. fowleri induced huge cytotoxicity over about $87 \%$. However, the protective effects of the monoclonal antibody of DG11 were not observed in the cytotoxicity of $A$. castellanii and $N$. fowleri at Table 2 and Fig. 2. It implied that the monoclonal antibody of DG11 be A. culbertsoni MBP-specific.

Contact-dependent pathway of $A$. culbertsoni via saccharides or proteins has been of interest. It was reported that other pathogenic $A$. castellanii have strong associated with MBP in the contact-dependent pathway (Kim et al., 2012). Recently, MBP of A. culbertsoni was purified and the monoclonal antibody of DG11 was produced and characterized

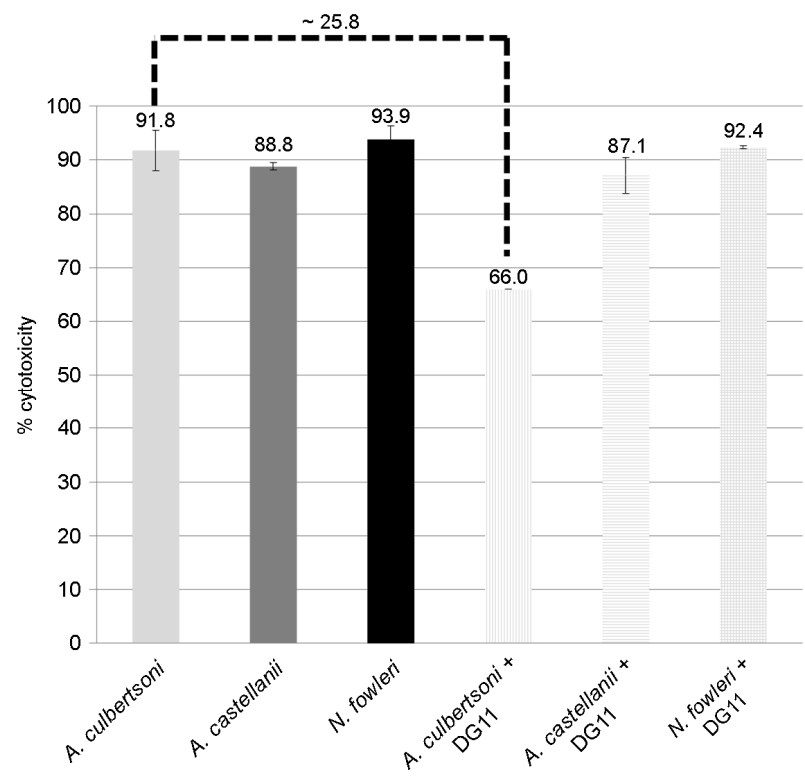

Fig. 2. Comparison of cytotoxicity by other free-living amoebae and the protective effects of DG11. Based on the LDH assay shown at Table 2 , the cytotoxicity was calculated with percent value.

Table 2. Comparison of protective effects of DG11 using other free living amoebae. Other three pathogenic strains were applied. Data were absorbances measured under $490 \mathrm{~nm}$. The experiments were performed in triplicate three times as shown at Table 1

\begin{tabular}{|c|c|c|c|c|c|c|c|c|c|c|c|c|}
\hline Exp. & Medium & $\mathrm{CHO}$ & $\begin{array}{l}\text { Lysed } \\
\mathrm{CHO}\end{array}$ & $\begin{array}{c}\text { Lysed } \\
\text { A. culbertsoni }\end{array}$ & $\begin{array}{c}\text { Lysed } \\
\text { A. castellanii }\end{array}$ & $\begin{array}{c}\text { Lysed } \\
N . \text { fowleri }\end{array}$ & $\begin{array}{c}\mathrm{CHO}+ \\
\text { A. culbertsoni }\end{array}$ & $\begin{array}{c}\mathrm{CHO}+ \\
\text { A. castellanii }\end{array}$ & $\begin{array}{c}\mathrm{CHO}+ \\
\text { N. fowleri }\end{array}$ & $\begin{array}{c}\mathrm{CHO}+ \\
\text { A. culbertsoni }+ \\
\text { DG11 }\end{array}$ & $\begin{array}{c}\mathrm{CHO}+ \\
\text { A. castellanii + } \\
\text { DG11 }\end{array}$ & $\begin{array}{c}\mathrm{CHO}+ \\
\text { N. fowleri }+ \\
\text { DG11 }\end{array}$ \\
\hline $1^{\text {st }}$ & 0.555 & 1.231 & 2.999 & 0.598 & 0.515 & 0.502 & 3.000 & 2.875 & 3.131 & 2.100 & 2.920 & 2.989 \\
\hline $2^{\text {nd }}$ & 0.458 & 1.234 & 2.567 & 0.675 & 0.599 & 0.563 & 3.215 & 2.901 & 3.011 & 2.313 & 2.888 & 2.991 \\
\hline $3^{\text {rd }}$ & 0.525 & 1.451 & 2.498 & 0.700 & 0.612 & 0.591 & 2.997 & 2919 & 2.984 & 2.208 & 2.719 & 3.003 \\
\hline Mean & 0.513 & 1.305 & 2.688 & 0.658 & 0.575 & 0.552 & 3.071 & 2.898 & 3.042 & 2.207 & 2.842 & 2.994 \\
\hline SD & 0.050 & 0.126 & 0.272 & 0.053 & 0.053 & 0.046 & 0.125 & 0.022 & 0.078 & 0.107 & 0.108 & 0.008 \\
\hline
\end{tabular}


with IgM (Kang et al., 2018). The monoclonal antibody of DG11 possessed kappa chain and about $83 \mathrm{kDa}$ (Kang et al., 2018).

In A. culbertsoni trophozoite, MBP concentrated in the movement would be associated with the adhesion of the amoeba to a host cell, leading to amoebial cytotoxicity. It was guided that if treated with antibodies, the cytotoxicity of A. culbertsoni would be inhibited. The protective effects of the monoclonal antibody of DG11 were shown about $37.5 \%$, which implied that MBP should be absolutely associated with adhesion and further amoebial cytotoxicity.

Rather than optical finding such as immunofluorescence for the cross-reactivity and specificity, quatification is needed for better understanding. The LDH release showed numerical results of the amoebial cytotoxicity and protective effects of the monoclonal antibody of DG11. As a result, other amoebae of $A$. casteallanii and $N$. fowleri did not show its protective effect against $A$. culbertsoni-specific MBP.

The antibody will be applied into an in vivo functional analysis, which would help to develop therapeutics.

\section{ACKNOWLEDGMENT}

This research was supported by Basic Science Research Program through the National Research Foundation of Korea (NRF) funded by the Ministry of Education (2017R1D1A1A02018651).

\section{CONFLICT OF INTEREST}

The authors have no conflicts of interest to disclose.

\section{REFERENCES}

Garate M, Cao Z, Bateman E, Panjwani N. Cloning and characterization of a novel mannose-binding protein of Acanthamoeba. J Clin Chem. 2004. 279: 29849-29856.

Kang AY, Park AY, Shin HJ, Khan NA, Maciver SK, Jung SY. Production of a monoclonal antibody against a mannosebinding protein of Acanthamoeba culbertsoni and its localization. Exp Parasitol. 2018. 192: 19-24.

Kang SY, Song KJ, Jeong SR, Kim JH, Park S, Kim K, Kwon MH,
Shin HJ. Role of the Nfa1 protein in pathogenic Naegleria fowleri cocultured with $\mathrm{CHO}$ target cells. Clin Diagn Lab Immunol. 2005. 12: 873-876.

Khan NA. Acanthamoeba: biology and increasing importance in human health. FEMS Microbiol Rev. 2006. 30: 564-595.

Kim JH, Matin A, Shin HJ, Park H, Yoo KT, Yuan XZ, Kim KS, Jung SY. Functional roles of mannose-binding protein in the adhesion, cytotoxicity and phagocytosis of Acanthamoeba castellanii. Exp Parasitol. 2012. 132: 287-292.

Lee YJ, Kim JH, Jeong SR, Song KJ, Kim K, Park S, Park MS, Shin HJ. Production of Nfa1-specific monoclonal antibodies that influences the in vitro cytotoxicity of Naegleria fowleri trophozoites on microglial cells. Parasitol Res. 2007. 101: 1191 $-1196$.

Panjwani N. Pathogenesis of Acanthamoeba keratitis. Ocul Surf. 2010. 8: 70-79.

Ryu JS, Im Ki. The production and characterization of antiNaegleria fowleri monoclonal antibodies. Korean J Parasitol. 1992. 30: 33-41.

Schuster FL, Visvesvara GS. Free-living amoebae as opportunistic and non-opportunistic pathogens of humans and animals. Int J Parasitol. 2004. 34: 1001-1027.

Seong GS, Sohn HJ, Kang H, Seo GE, Kim JH, Shin HJ. Production and characterization of monoclonal antibodies against cathepsin B and cathepsin B-Like proteins of Naegleria fowleri. Exp Parasitol. 2017. 183: 171-177.

Sissons J, Kim KS, Stins M, Jayasekera S, Alsam S, Khan NA. Acanthamoeba castellanii induces host cell death via a phosphatidylinositol 3-kinase-dependent mechanism. Infect Immun. 2005. 73: 2704-2708.

Walochnik J, Aichelburg A, Assadian O, Steuer A, Visvesvara G, Vetter N, Aspöck H. Granulomatous amoebic encephalitis caused by Acanthamoeba amoebae of genotype $\mathrm{T} 2$ in a human immunodeficiency virus-negative patient. J Clin Microbiol. 2008. 46: $338-378$

https://doi.org/10.15616/BSL.2018.24.4.435

Cite this article as: Park AY, Kang AY, Jung SY. Protective Effects of a Monoclonal Antibody to a MannoseBinding Protein of Acanthamoeba culbertsoni. Biomedical Science Letters. 2018. 24: 435-438. 